\title{
Sustainable development in the shadow of climate change
}

\section{Desenvolvimento sustentável à sombra da mudança climática}

Desarrollo sostenible en la sombra del cambio climático

Richard Stahel ${ }^{1}$

\begin{abstract}
Development plans at different levels - from local to global - aspire to eliminate poverty, famine, to make health care accessible, to create better access to education, to improve transportation, employment, and the quality of life, all within next decades. Yet, these plans collide with the reality of climate change, more precisely the Anthropocene, which already creates high-dimensional conflicts. These will only intensify within decades because climate change and other consequences of the environment global devastation lead to a real decrease of resources. These resources enable not only development but also an elementary reproduction of the essential preconditions of life. The current model of development has substantially contributed to the intensification of unequal accessibility to resources and existing conflicts have thus heightened and new ones have emerged. Water as an essential resource will cause new conflicts. Growing population, expansion of deserts and a sea level rise then increase conflicts for the land. Heat waves occur more often which strengthens conflicts for land suitable for human life, meaning that inhabitable areas are spreading. Therefore there is a need to re-evaluate the character and hierarchy of resources and their accessibility, and also concepts of development. The existing development of humankind has been done at the expense of others in many cases and mainly at the expense of the environment. The current situation raises a question of climate justice from both historical and systematic viewpoints. It opens a need to reformulate the concept of human rights from the perspective of their essential environmental preconditions and to define the status of environmental migrants.
\end{abstract}

Keywords: Climate change. Environmental migrants. Concepts of development. Sustainability. Climate justice.

Resumo: Os planos de desenvolvimento em diferentes níveis - do local ao global - aspiram eliminar a pobreza, a fome, tornar acessível a assistência médica, criar melhores acessos à educação, melhorar o transporte, o emprego e a qualidade de vida, tudo nas próximas décadas. No entanto, esses planos colidem com a realidade da

\footnotetext{
${ }^{1}$ Institute of Philosophy, Slovak Academy of Sciences (Bratislava, Slovakia). author_biographical_data
} 
mudança climática, mais precisamente, com o Antropoceno, que já cria conflitos de grandes dimensões. Esses planos de desenvolvimento só irão se intensificar dentro de décadas, porque as mudanças climáticas e outras consequências da devastação global do meio ambiente levam a uma efetiva diminuição dos recursos. Eles permitem não apenas o desenvolvimento, mas também uma reprodução elementar das pré-condições essenciais da vida. O modelo atual de desenvolvimento contribuiu substancialmente para a intensificação da acessibilidade desigual aos recursos e os conflitos já existentes aumentaram e novos surgiram. A água como recurso essencial causará novos conflitos. Assim, a população crescente, a expansão dos desertos e o aumento do nível do mar aumentarão os conflitos pela terra. A frequente ocorrência de ondas de calor fortalecerá os conflitos por uma terra adequada à vida humana, o que significa que as áreas habitáveis aumentarão gradualmente. Portanto, há uma necessidade de reavaliar a qualidade e a hierarquia dos recursos e sua acessibilidade, bem como os conceitos de desenvolvimento. O desenvolvimento da humanidade tem sido feito em detrimento de outros recursos em muitos casos e, principalmente, às custas do meio ambiente. A situação atual levanta uma questão de justiça climática tanto do ponto de vista histórico quanto sistemático. Isso abre a necessidade de reformular o conceito de direitos humanos a partir da perspectiva de suas pré-condições ambientais essenciais e definir a condição dos migrantes ambientais.

Palavras-chave: Mudanças climáticas. Migrantes ambientais. Conceitos de desenvolvimento. Sustentabilidade. Justiça climática..

Resumen: Los planes de desarrollo a diferentes niveles, de local a global, aspiran dentro de las próximas décadas eliminar la pobreza, el hambre, a hacer accesible el sistema de cuidado de la salud, a crear un mejor acceso a la educación, a mejorar el transporte, el empleo y la calidad de vida. Sin embargo, estos planes chocan con la realidad del cambio climático, más precisamente con el Antropoceno, que ya crea conflictos de grandes dimensiones. Estos sólo se intensificarán dentro de décadas, debido a que el cambio climático y otras consecuencias del entorno devastador global conducen a una disminución real de los recursos. Estos recursos permiten no sólo el desarrollo, sino también una reproducción elemental de las condiciones previas esenciales de la vida. El modelo actual de desarrollo ha contribuido sustancialmente a la intensificación de la accesibilidad desigual a los recursos y los conflictos existentes han aumentado y han surgido otros nuevos. El agua como recurso esencial causará nuevos conflictos. La creciente población, la expansión de los desiertos y el aumento del nivel del mar aumentan los conflictos por la tierra. Las olas de calor ocurren con mayor frecuencia, lo que fortalece los conflictos por una tierra adecuada para la vida humana, lo que significa que las áreas habitables se están extendiendo. Por lo tanto, es necesario volver a evaluar el carácter y la jerarquía de los recursos y su accesibilidad, así como los conceptos de desarrollo. El desarrollo de la humanidad hasta ahora se ha hecho a expensas de otros y en muchos casos, principalmente, a expensas del medio ambiente. La situación actual plantea una cuestión de justicia climática desde puntos de vista tanto históricos como sistemáticos. Abre la necesidad de reformular el concepto de derechos humanos desde la perspectiva de sus condiciones ambientales esenciales y definir el estado actual de los migrantes ambientales.

Palabras-clave: Cambio climático. Migrantes ambientales. Conceptos de desarrollo. Sostenibilidad ambiental. Justicia climática. 


\section{Introduction}

Development plans at different levels - from local to global - aspire to eliminate poverty, famine, to make health care accessible, to create better access to education, to improve transportation, employment and the overall quality of life, all of these within next decades. Development plans adopted at the UN summit in New York in September 2015 with the 2030 Agenda for Sustainable Development (UN, 2015a) are an effort to fulfill ideals of humanity with an ambition to be the new universal standard for development accessible to all people. On the other hand, they actually try to realize the concept of sustainable development, which is quite problematic. Considering risks and threats the most important of the 2030 Agenda's 17 goals is number 13 (UN, 2015a, 25). Its ambition is to combat climate change and its impacts, and its fulfillment is a precondition of all other development goals. Since a significant change in the global climate system would make most of the other goals impossible.

It is still true that every development needs quite a lot of resources people, finances, materials and also environmental resources. We can see that this also applies to sustain the current state of development. The current technology level needs, even for only rescue operations, many non-renewable resources. Consumption of these is only another source of greenhouse gas emissions and other materials which pollute the environment. At the same time, climate change and impact of the global devastation of the environment lead to a decrease of those resources which enable development and a simple reproduction of the essential preconditions of life. Climate change and depletion of resources are one of the main reasons for current conflicts and there is no indication of the inverse, at least in the medium term.

\section{Catastrophes and collapses}

The year 2016 was the warmest year on record and 2017 was even warmer. The year of 2016 was also the year with the record carbon dioxide $\left(\mathrm{CO}_{2}\right)$ spike in the atmosphere. ${ }^{1}$ The hurricane season of 2017 also broke records - in size of storms, number, frequency, material damages and casualties in southeast

\footnotetext{
${ }^{1}$ In 2016 the level of carbon dioxide in the atmosphere reached 403,3 ppm (parts per million), 3,3 ppm more than in 2015. According to a WMO report such a concentration of carbon dioxide in the atmosphere was three to five million years ago, when the temperature was a $3^{\circ}$ higher and the sea level ca. 20 meters higher (WMO, 2017). The problem is not only the concentration of greenhouse gases in the atmosphere, but also the fact that from the geology-climate viewpoint this increase happened unprecedentedly fast.
} 
Asia, Caribbean and southern parts of the USA. Forest fires caused huge material and environmental damages. In 2017 millions of people, mainly in Africa, but also on Arabian Peninsula or in India, suffered from hunger ${ }^{2}$ caused by a long drought, expansion of deserts, and heat waves. The latter two are becoming common also in the temperate climate countries. Hurricanes, floods, sea level rise, heat waves, forest fires and expansion of desert leave millions of people without livelihood; without land that gives them food; without water that keeps them alive; and without shelter. Millions of people thus lose even the little they had and they fall deeper into poverty. This proves that climate change also deepens the poverty of a significant part of the human population, and the difference between the richest and poorest people widens (Beck, 2010b, p. 171). In other words, in many countries, climate change impact devastates their level of development.

All of these are manifestations of climate change. They significantly influence the lives of millions of people, while the emissions of greenhouse gases will in an ideal case continue for many years. It is apparent, that, if in a short space of time the greenhouse gas emissions are not curbed, Southeast Asia will suffer from heat waves incompatible with human life even if people take precautions - drink enough water and sit in shade (Im et al., 2017). Millions of people in that area cannot stay in air-conditioned rooms, because they live in very poor rural areas. At the moment, $30 \%$ of world population suffer, and by the end of the century, with the current trend in greenhouse gases emissions, it will be more than $50 \%$. The number of casualties caused by climate change will be much higher, as will also be the number of environmental refugees, nowadays already tens of millions, ${ }^{3}$ because uninhabitable areas will spread.

All these and other phenomena have been for almost two decades called the Anthropocene. This term denotes a new geological and climate epoch created by humans with all their activities. The concept of the Anthropocene origins in the idea that because of industrialism, ${ }^{4}$ urbanization, and exponential

\footnotetext{
${ }^{2}$ Approximately 815 million people, around $11 \%$ of the world population suffer from hunger and malnutrition. After 10 years of a mild decrease of the starving, in 2016 the number has increased again (FAO; Ifad; Unicef; WFP; WHO, 2017). The reason for this are climate change, armed conflicts, but also stock speculations.

3 According to the Office of the United Nations High Commissioner for Refugees (UNHCR) circa 65,6 millions of people have been forced out from their homes in June 2017. This is the highest level of displacement since the Office was created (UNHCR, 2017). It is expected that due to climate change (as one of the factors) in the next few years the number of refugees will increase to 200 million.

${ }^{4}$ Industrialism is seen not only as a form of mass production of energy and different kinds of goods, but also agriculture and sea fishing have industrial character since 1950's. Additionally, we have tourist industry, music and film industry, or more precisely industry of entertainment and information. All these activities are characterized by high energy demands, concentration
} 
growth of the human race in the last two centuries the extent of our influence on the environment has reached such a level that people have become a geological and climate force. The Anthropocene is then an unwanted byproduct $^{5}$ of human activities, such as pollution, extensive use of plastic and concrete, nuclear weapons tests ${ }^{6}$ or factory farming of domesticated animals. ${ }^{7}$ All of these and many other activities leave their marks (identifiable by geological and climatological methods) comparable to changes that happened in geological and climate turning points of the development of our planet and its climate. Shortly - it is humankind (or its life strategy created by evolution that has culminated in the industrialism of the last two centuries), which is the main reason of ending the stable epoch of the Holocene, which enabled agriculture $^{8}$ and thus the rise of global civilization.

Climate change consequences ${ }^{9}$ are such that not only peripheral areas but also significant parts of the densely populated continents face the threat of becoming uninhabitable. Another consequence of the unstable Anthropocene climate and its extremes, such as heat waves, torrential rains, hurricanes with high-velocity winds, is a threat to food production and availability of potable

and centralization, which then require long-distance, often intercontinental transport of a large amount of goods and people. All these activities have therefore very significant, and mainly negative impact on the quality of all components of the environment.

${ }^{5}$ For example, thousands of kinds of pesticides, herbicides, insecticides and other agro chemistry products are used to increase the agro production primarily, not to pollute the land and contaminate the ground and surface waters; just as the primary use of Freon wasn't to deplete the ozone layer, and when the technologies burning fossil fuels spread it wasn't with the goal to cause climate change, etc.

${ }^{6}$ Since the first nuclear test on July 15 in 1945 until now 2055 nuclear explosions were detonated, many of them in the atmosphere or in the oceans, there were also several nuclear accidents. These activities only added to the change of chemical and physical properties of the ecosphere on global scale.

${ }^{7}$ For definition of the Anthropocene, see Steffen et al. (2011) and also Steffen et al. (2015).

${ }^{8}$ Agriculture needs stable climate conditions and recurring meteorological phenomena, which were so characteristic for the Holocene epoch that agricultural terms of all the ancient civilizations were derived from astronomical phenomena. Arrival of floods (in ancient Egypt) or monsoon rains (in ancient India) occurred so regularly that the rhythm of social, religious, and agricultural life was organized accordingly. Because of this predictability, people settled down and it enabled the formation of the civilization.

${ }^{9}$ Climate change is only one of the manifestations of the environmental crisis. Pollution of the atmosphere, rivers and oceans, as well as contamination of the land by industrial products, i.e. by compounds and materials such as plastics, is so vast and intensive that in many areas it is highly visible not only by measuring instruments but even by our limited sight. There is also the growth of deforestation or devastation of traditional habitats of sea fauna by fishing industry, or extinction of many species of animals and plants by hunting, but mainly extension of urbanized areas and areas used for agricultural production gained at the expense of wilderness (Steffen, 2015). In this context the arguments of climate skeptics questioning the existence of climate changes, their seriousness and their human origin are irrelevant, because the devastation and pollution of the eco-system, which are undoubtedly a consequence of human activities, are so vast and serious even without climate change that they are threatening essential preconditions for further existence of humankind. 
water - with hundreds of millions people already suffering, especially in the tropics and subtropics. The Anthropocene then has significant social, economic as well as political consequences manifested in the form of social, political, and even armed conflicts of various intensity and extent. Economic, social, and political institutions of today's society were established in the Holocene epoch, ${ }^{10}$ and as such many of them are not able to react to the threats and risks of the Anthropocene (Angus, 2016; Davies, 2016). We can see the failure of these institutions (and also the infrastructure) in the growing number of conflicts, in which climate change is a detonator or multiplier of the conflict potential, represented in different areas by social, ethnic, religious, or political risks and threats (The Environmental Justice Foundation, 2017).

\section{Paradox of global risks and local conflicts}

It is apparent that the so-called weather-induced conflicts are increasing, while many of them are high-dimensional conflicts and the primary reason is hard to identify. The reason or dimensions of conflicts are usually climate or environmental, as well as social, ethnic, religious, or political. Paradoxically, it may seem that climate change, i.e. the global phenomenon, causes the most intensive conflicts mainly at a local level. Conflicts burst out in places where the environment changes radically and does not provide basic preconditions for life (food, water) anymore. Additionally, the conflicts burst out also in areas where people escape when running from the consequences of climate change. This phenomenon has so far been very intensive in the tropics and subtropics, i.e. in densely populated areas. People try to escape to a temperate climate and it is more than likely that the number of migrants from these countries will increase.

In the problematic areas, where deserts spread, sea level rises, or hurricanes appear (with torrential rains causing floods and landslide), almost always identical problems appear. For example, where to get enough potable water, at least some food and shelter, if not adequate housing for all of the affected. The hurricane Katrina in 2005, hurricane Sandy in 2012 and consequences of the 2017 hurricane season prove that to provide these preconditions of survival is often more than even the USA, statistically, the richest country in the world can handle. Poorer countries have far less possibilities only to evacuate people from the most affected areas and to take care of all those people who often lost literally everything.

\footnotetext{
${ }^{10}$ This is true for most of the transport, communication, energy or residential infrastructure. E.g. almost a fifth of the world population lives in areas with a high risk of sea level rise.
} 
People in areas affected by a catastrophe almost inevitably find themselves in the midst of the Hobbes's war of all against all for limited resources, which help them survive, although the supplies will last only for a day or two. In addition, public institutions fail to provide even basic security. Looting and raping is then a prevalent accompanying phenomenon.

Consequently, global reasons cause conflicts on local levels. Local institutions have limited or no possibilities to really solve these conflicts. This is based on a simple fact that their representatives are often also affected by the loss of access to basic resources, shelter, or family members, just like the others. This global failure challenges the meaningfulness and legitimacy of these institutions. "Thus, the scope for action contracts precisely at those moments in which it needs to drastically expand" (Habermas, 2005, p. 69). The collapse of action readiness and therefore often of legitimacy of public institutions can grow into long-term conflicts, such as the ones in Darfur, Somalia, Afghanistan, ${ }^{11}$ or Syria ${ }^{12}$ - one of the main reasons of war and existence of these conflicts ${ }^{13}$ in these countries is a fight for diminishing resources, such as water (St'ahel, 2016b) and land. For example, the merciless and fiercest fights in these areas are fights for water ${ }^{14}$ - this is a significant feature of the conflicts in Libya or Palestine.

In less developed countries with less educated people, manifestations of climate change such as drought, hurricanes, or floods will be explained theologically, or more often, the phenomenon of a return to the original tribal or religious identities (tribalization) will appear as a defense reaction of people affected by the loss of security (food, water, personal) as a consequence of public institutions collapse. This will probably intensify the wave of religious fundamentalism and separatism. Paradoxically, the rise of education in the

\footnotetext{
${ }^{11}$ According to World Food Programme, Unep, and the National Environmental Protection Agency (Nepa) the biggest climate hazards to Afghan livelihoods are drought and floods, caused by irregular snowmelt or rainfall (WFP; Unep; Nepa, 2016). "According to the Unep, about $80 \%$ of conflicts in Afghanistan are related to resources like land and water - and to food insecurity, an immediate consequence of global warming" (Rasmussen, 2017).

${ }^{12} \mathrm{On}$ the role of climate changes in the outbreak of the civil war in Syria see Kelley; Mohtadi; Cane; Seager and Kushnir (2015).

${ }^{13}$ In the beginning of June 2017 António Guterres, the UN Secretary-General, pointed out that at present more than 800 million people lack basic potable water service and more than 2,5 billion people lack even basic sanitation services. With the current growth rate of consumption of potable water its demand will grow by 2050 by more than $40 \%$. This means that at least a quarter of the world population will live in countries with a "chronic or recurrent" water shortage (WHO; Unicef, 2017).

${ }^{14}$ From 1947 to 2017 there were approximately 37 interstate conflicts connected with water. In many other, mainly internal conflicts an access to water played a key role, or better to say many fight were fought for water sources; or a limited access to water or a destruction of water supply infrastructure was used as a significant tool to break the resistance of one of the fighting parties.
} 
countries of the global South can cause a similar effect. More schooled people are becoming aware of the colonial oppression of the rich global North and of the fact that a great part of the wealth of the North comes from social and environmental exploitation of the global South in the past, and from climate injustice of the present. The majority of the greenhouse gases that cause climate change were emitted into the atmosphere in the last two centuries mainly in the countries of the rich global North, but it has the most serious impact on the global South. Awareness of this social, economic, and environmental injustice and inequality together with a growing demand for equality as a paradoxical consequence of the Euro-American human rights discourse of last decades ${ }^{15}$ can lead to a movement that would be a continuation of the anti-colonial liberation movements of the second half of previous century. However, this time at a global level.

\section{Climate justice and the concept of development}

The present situation thus puts the question of climate justice - from historical and the systematical viewpoint. At a global level, these conflicts can be interpreted as a fight for global justice, or more precisely as socialenvironmental conflicts between the rich North and poor South. The main source of greenhouse gas emissions is industrialization, including the industrialization of agriculture and tourism. This became possible with the use of fossil fuels, first coal, then oil and natural gas. Industrialization began in the late 1700's in Western Europe and until the 1950's the most greenhouse gases were produced by industrial, military and transport activities of Europe and North America. ${ }^{16}$ The climate change is mostly manifested in those regions,

\footnotetext{
${ }^{15} \mathrm{U}$. Beck points out that, "Even if inequalities are not growing, the expectations of equality are increasing and, in the process, are de-legitimizing and destabilizing the system of nationalglobal inequalities. 'Developing nations' are becoming more westernized and reflect the West back to itself, so that the 'equality' of environmental destruction leads to the self-destruction of civilization. The overlap, one might also say, the collision of growing global expectations of equality (human rights) and growing global and national inequalities, on the one hand, namely with the radically unequal consequences of climate change and the consumption of resources, on the other, could soon sweep away this whole set of premises of a nationally confined inequality, just as Hurricane Katrina swept away the houses of the poor in New Orleans" (Beck, 2010a, p. 257).

${ }^{16}$ Most of the greenhouse gas emissions come from the production of steel and electric power in thermal power plants burning coal, and from transport activities, such as railway and maritime transport, later air transport and road transport, or better to say motoring in general. Millions of tons of $\mathrm{CO}_{2}$ come only from maritime and air transport serving mainly the citizens of the global North. Greenhouse gas emissions from this transport are not included in the calculations and therefore are not in the obligations, which the signatories of the Paris Climate Agreement committed to reduce their emissions. Moreover, $63 \%$ of the world's industrial emission of $\mathrm{CO}_{2}$ and methane between years 1751-2010 was produced by only 90 corporations. Most of these companies have mined and processed coal, oil and natural gas, only 7 produced cement,
} 
which have not profited from the growth of the living standard in Europe and North America, on the contrary, they were colonized and socially and environmentally exploited. The efforts to come to terms with the colonial past are part of the dispute for climate justice. Many countries of the global North do not have the willingness to take this step.

Moreover, it is apparent that even limiting the increase in the global temperature to $2{ }^{\circ} \mathrm{C}$, which is the goal of Paris climate agreement (UN, 2015b) ${ }^{17}$ will not guarantee protection from extreme weather events and rising sea levels, or from the need to leave most coastal cities. "The economic and social cost of losing functionality of all coastal cities is practically incalculable" (Hansen et al., 2015). The need to resettle tens of millions of people from the coastal cities will not be achieved without conflicts and fights over those territories to which these people can be moved. Simultaneously, the process of desertification will continue and lead to millions of people being uprooted from their current homes. They will also need new places to live. Desertification and increase in temperature will extend uninhabitable areas (Park et al., 2018), or they will be habitable at the price of high investments into energy and transport infrastructure, air-conditioning of all buildings, investments into desalination devices, and into transportation of all food from a great distance, since areas such as North Africa and the Middle East, which cannot produce enough food for their population, will be on the increase. Logically, only rich countries or people can afford this. However, climate change will hit poor countries the hardest regions like the Mediterranean, Africa, Middle East, Persian Gulf, Pakistan,

production of which is also source of a lot of greenhouse gases (Heed, 2014). However, signatories of the Paris Climate Agreement are states (governments). This means that states committed to reduce the greenhouse gas emissions, but because of globalization states as such have only very limited possibilities to regulate activities of corporations.

${ }^{17}$ The signing of the Paris Climate Agreement in December 2015 was celebrated as a fundamental breakthrough in the effort to mitigate climate change and the social-political conflicts resulting from it. This is so far the most significant agreement regarding climate change and, once ratified, it will replace the Kyoto Protocol in 2020. The significance of this agreement lies mainly in the fact that 196 states have acknowledged that the phenomenon of anthropogenic climate change exists and that it constitutes a threat, and that they have agreed to deal with it. Its weakness is that the goals to reduce greenhouse gas emissions set by individual states are voluntarily and there is no mechanism to enforce these obligations. It is not clear yet if the agreement will be ratified by all countries, even though in 2016 it was ratified not only by EU, but also by China, India and even the USA, so by countries that produce the most greenhouse gases. US president pulled out his country from this agreement in June 2017, and at the same time he lifted bans on mining coal and oil in the USA, which means it continues to prefer fossil economy. Because of this, it is not clear how other countries would fulfill the agreement, if they will change their energy policies, or when and in what form they will do it. Only subsidies to mining and consumption of coal and other fossil fuels are many times higher than subsidies to building energy sources using renewable sources of energy (Harris, 2011;2014; 2016). Burning coal is still one of the biggest source of greenhouse gas emissions. 
India, or Bangladesh. Other areas that can be affected are sub-mountain areas of the Andes or the Himalayas, where most of the water resources and local food production depend on glacier-fed rivers; and if the glaciers continue to melt at their current pace, they will totally retreat in the next few decades.

If we are not able to quickly and radically reverse these trends, we can assume that in future more and more conflicts for water and land (as basic preconditions of life) will appear, ${ }^{18}$ just like these conflicts intensified during a temperature increase in the past (Hsiang et al., 2013). The only solution for the poor, who are a majority in these most affected regions, is to migrate from the tropics and subtropics to temperate climate countries, and so it is very likely that in the next few decades the mass migration will increase (Missirian et al., 2017). The growing number of environmental migrants already collides with the unwillingness of the developed countries of the global North to give asylum to other than political migrants. There is no generally accepted definition of an environmental migrant or refugee and a right of asylum for environmental reasons does not exist, so the environmental asylum seekers in countries with a temperate climate are refused as they are perceived as economic migrants.

Reflection of these phenomena leads to studying the importance and sustainability of those basic principles around which the current economic and political system is organized at the local and global level. It creates the need to reformulate the concept of human rights from the perspective of essential environmental preconditions (St'ahel, 2016a); the concept of citizenship; the right for asylum; the right for political and cultural identity (this applies to migrants as well as citizens of the destination countries of migrants); the concept of sovereignty itself (Kocina, 2017); and finally, the need to define the status of an environmental migrant.

Additionally, the concept of development itself needs to undergo such a critical study, because the existing development of humanity has been realized at the expense of others, ${ }^{19}$ mainly at the expense of the environment. Climate change and its social and political consequences ${ }^{20}$ show quite clearly that the

\footnotetext{
${ }^{18}$ As F. Jameson emphases, „,Whether you think of the question of Palestine, the settlements and camps, or of the politics of raw materials and extraction; whether you think of ecology (and the rainforests) or the problem of federalism, citizenship, and immigration, or whether it is a question of gentrification in the great cities as well as in the bidonvilles, the favelas and the township and of course the movement of the landless - today everything is about the land. In Marxist terms, all these struggles result from the commodification of land, the dissolution of the last remnants of feudalism and its peasantries, and their replacement by industrial agriculture or agribusiness and farmworkers" (Jamieson, 2016, p. 13). The land is simply a basic nonrenewable resource, and its availability decreases also as a result of the population growth.

${ }^{19}$ Mainly at the expense of lower class and population of colonized countries.

${ }^{20} \mathrm{On}$ the problem of climate justice and social conflicts in the age of climate change see Tokar (2014) and St'ahel (2016c).
} 
planet Earth is not big enough for the current models of development, which means that these models are not socially and environmentally sustainable. Mainly in the tropics and subtropics, change the development plans too often due to catastrophic floods, hurricanes, or droughts, to rescue operations. Several development plans even become the source of conflicts or accelerate existing conflicts, ${ }^{21}$ many of which result from climate change. However, climate models predict that the situation will worsen by the end of the century. Maybe it is time, as James Lovelock writes, to start considering a concept of retreat, ${ }^{22}$ more than a development concept, because "sustainable development simply means growth" (Lovelock, 2014, p. 108). Instead, "we continue to plan for the future as if climate scientists don't exist" (Hamilton, 2017).

If we accept the concept of degrowth ${ }^{23}$ or concept of sustainable retreat, as Lovelock suggests, we cannot ignore nor deny the reality of climate change anymore. There are only indications so far, that climatology knowledge would be reflected in actual politics. If the concept of development is replaced by the concept of survival, it is possible to see a significant decrease of greenhouse gas emissions, even low-carbon or decarbonized economy. This means that the imperative of growth needs to be replaced by the imperative of survival. And such a fundamental paradigm shift requires a very strong impulse.

According to Beck (2015, p. 79), it paradoxically can be climate change itself as a risk of a global catastrophe. We need to focus on "the positive side effects of bads. They are producing normative horizons of common goods. Global risk may be destructive nationally ('working institutions fail') but creating opportunities globally ('new normative horizons' and the emergence of unwritten but imperative norms)". This is based on his world risk society theory; he anticipates a hidden emancipatory side effect of the global risk, which is climate change: "The global climate risk ... is ... a kind of "emancipatory catastrophe"" (Beck, 2015, p. 79). He claims that: "The transformation of the world produced by the emancipatory side effects of the bads of world

\footnotetext{
${ }^{21} \mathrm{~A}$ common source of conflicts is an effort to speed up a development of a region by building a highway (or a power plant, a factory, a tourist resort, etc.) through a protected area, a land of indigenous peoples or small farmers or land owners.

${ }^{22}$ The concept of sustainable retreat is based on the fact that due to the devastation of the ecosphere, of which climate change is only one of the consequences, it is too late to implement the concept of sustainable development. Therefore it is necessary to think about a retreat to areas that are likely to stay habitable even after the sea level rise and desertification; it is necessary to think about how to move millions of people from areas flooded by sea or absorbed by desert; to think about a change of the way of life, of production of food and energy so that not only humankind as animal species would survive, but also our civilization and its technological and organizational knowledge. See more Lovelock (2006).

${ }^{23}$ For the concept of degrowth see D'Alisa; Demaria; Kallis (2015) and also Hohoš (2016) and Sklair (2016).
} 
risk society can be seen, and analyzed by using three conceptual lenses: first, the anticipation of a global catastrophe violates sacred (unwritten) norms of human existence and civilization; second, thereby it causes an anthropological shock, and, third, a social catharsis" (Beck, 2015, p. 79). ${ }^{24}$ The anthropological shock, according to Beck, creates "a cosmopolitan moment", in which it is possible to replace non-functional or ineffective institutions and imperatives by new ones, adequate for the nature of risks that humanity faces. Humankind has never faced a greater threat than this climate change and our future depends on the fact if we are able to create and enforce new imperatives and institutions fast enough.

On the background of Beck's concept of emancipatory catastrophism, there is a concept of humanity, or a premise of the ability and willingness to leave the tribal, national or state framework of common good. It is questionable if we can expect a fast spread and acceptance of a transnational or cosmopolitan framework. The current reactions of several countries to global risks and migration suggest opposite trends: a shift from international and multinational cooperation to isolationism, even nationalism, separatism, extremism, and tribalism.

Lovelock (2014, p. 147) pointed at the threat of this shift even before the migrant crisis began in 2015. He said that "tribalism is so strongly a part of our natures that there is little chance that benign education, ${ }^{25}$ selective breeding or genetic manipulation can be used to alter it. Like it or not, when confronted with an invasive threat to our territory we will respond tribally. On the other hand, when confronted by a huge natural disaster, the idea that we all belong to humanity as if it was our tribe, evokes little response, unless the disaster affects us directly". This appears to be closer to reality, i.e. to the real reactions of individuals and states to the series of natural disasters in 2017 mentioned above, than Beck's expectations of a social catharsis at the global level. Rather than cosmopolitanism, we can see renationalization from which Beck warned. Many states tighten asylum legislation, build border walls, or leave international organizations, or treaties so as to close themselves up from the

\footnotetext{
${ }^{24}$ For example the hurricane Katrina (29 Aug. 2005). Beck sees its emancipatory effect in the fact that reflection of the consequences of this catastrophe caused a paradigmatic shift towards unification of two separated discourses - racial and environmental. "It was this social catharsis that led to the emergence of a new normative horizon, namely the global justice frame, i.e. produced a common good as a side effect of bads. Katrina made it clear that climate catastrophe and racial inequality are closely interlinked. This made obvious the inseparable connection between climate change and global social justice" (Beck, 2015, p. 80).

${ }^{25}$ It is highly probable that this would be actual also if education for global citizenship will be in reality part of education at every school in countries all over the world as Mravcova assumes (2017).
} 
growing number of migrants. In many countries, many of their citizens support this policy of "tribalization". Lovelock $(2014$, p. 148) predicted this trend when he observed: "The concept of humanity or the human race sound good in political exhortations and sermons but are essentially beyond the perception of most of us" ${ }^{26}$ If this is so, then it is very likely that with the intensification of climate change and a growing number of migrants there will be more conflicts, which will also take new forms and extent of which is hard to assume. J. Lovelock then asks a disturbing question: "The rational and decent concept of humanity as the ultimate unit for world governance seems so well established that it is pointless to challenge it. But what if in reality the tribe or nation is the largest possible unit?" (Lovelock, 2014, p. 152). Even the affirmative answer to this question should not be a reason for pessimism. It would only mean that we need to put a stronger emphasis on our ability to cultivate mechanisms and forms of cooperation or at least mitigate conflicts between and within the states now more than ever.

\section{Conclusion}

All of these conflicts result from the fact that humankind tries to resolve problems created by industrialization, urbanization, and globalization through life and political strategies of the past. However, these strategies were created in the time when people were not facing a global environmental crisis and climate change. The future of humankind depends on the ability of people to change their life strategies before the planet's environment stops supporting the existence of the global civilization. The future of humankind, therefore, depends on the fact if people are able to leave the principles of competition and profit and are willing to replace them with principles of sustainability and selfless cooperation. It is this ability of cooperation and especially willingness to such cooperation that will decide the future of humankind.

Although, it is apparent that the condition and possibilities of the environment are not of peripheral importance, but are the central theme or even the basic assumptions of all thinking about politics and society, i.e. thinking about models of development that pretend to be relevant today. To keep living in our current conditions, human civilization lives on credit, and it mainly borrows from the environment. Finances for development could be taken from the resources used for armament, or existence of tax paradises or policies of tax dumping could be limited. Nevertheless, environmental resources of

\footnotetext{
${ }^{26}$ Especially if the cooperation and self-limitation in consumption is expected from generation that has been for the past decades indoctrinated by neoliberal ideology, which preferred competition and disrespected cooperation and solidarity. More in St'ahel (2017).
} 
development are limited by the growth limits - or more precisely sustainability - and in many countries, these limits have already been exceeded.

\section{Acknowledgement}

This article is part of Vega project 1/0291/18 Historic-philosophical analysis of environmental thinking, research on its influences on ethical, legal and political thinking and its social response.

\section{References}

ANGUS, Ian. Facing the Anthropocene: fossil capitalism and the crisis of the Earth system. New York: Monthly Review Press, 2016.

BECK, Ulrich. Climate for change, or how to create a green modernity? Theory, Culture \& Society, v. 27, n. 2-3, p. 254-266, 2010a. https://doi.org/10.1177/0263276409 358729

BECK, Ulrich. Remapping social inequalities in an age of climate change: for a cosmopolitan renewal of sociology. Global Networks, v. 10, n. 2, p. 165-181, 2010b. https://doi.org/10.1111/j.1471-0374.2010.00281.x

BECK, Ulrich. Emancipatory catastrophism: what does it mean to climate change and risk society? Current Sociology, v. 63, n. 1, p.75-88, 2015. https://doi.org/ 10.1177/0011392114559951

D'ALISA, Giacomo; DEMARIA, Federico; KALLIS, Giorgos (eds.). Degrowth: a vocabulary for a new era. New York: Routledge, 2015. https://doi.org/10.15173/ glj.v8i3.3217

DAVIES, Jeremy. The birth of the Anthropocene. Oakland: University of California Press, 2016.

FAO, IFAD, Unicef, WFP and WHO. The state of food security and nutrition in the world 2017. Building resilience for peace and food security. Rome: FAO, 2017.

HABERMAS, Jürgen. Legitimation crisis. Boston: Beacon Press, 2005.

HAMILTON, Clive. The great climate silence: we are on the edge of the abyss but we ignore it. The Guardian, May 5, 2017. Available: www.theguardian.com/ environment/2017/may/05/the-great-climate-silence-we-are-on-the-edge-of-theabyss-but-we-ignore-it.

HANSEN, James; SATO, Makiko; HEARTY, Paul; RUEDY Reto; KELLEY, Maxwell et al. Ice melt, sea level rise and superstorms: evidence from paleoclimate data, climate modeling, and modern observations that $2{ }^{\circ} \mathrm{C}$ global warming is highly dangerous. Atmospheric Chemistry and Physics, v. 15, p. 20059-20179, 2015. https:// doi.org/10.5194/acpd-15-20059-2015 
HARRIS, Jerry. Going green to stay in the black: transnational capitalism and renewable energy. Perspectives on Global Development and Technology, v. 10, p.41-59, 2011. https://doi.org/10.1163/156914911x555099

HARRIS, Jerry. Can green capitalism built a sustainable society? Perspectives on Global Development and Technology, v. 13, p.43-60, 2014. https://doi.org/ $10.1163 / 15691497-12341288$

HARRIS, Jerry. The transformation of capitalism and the limits of democracy. In: Johann P. Arnason; Marek Hrubec (eds.): Social revolution and transformation. Edinburgh, Edinburgh University Press, 2016. p. 56-75.

HEED, Richard. Tracing anthropogenic carbon dioxide and methane emissions to fossil fuel and cement producers, 1854-2010. Climatic Change, v. 122, n. 1-2, p. 229-241, 2014. https://doi.org/10.1007/s10584-013-0986-y

HOHOŠ, Ladislav. A tentative scenario of "sustainable degrowth society". Philosophica Critica, v. 2, n. 1, p. 59-64, 2016.

HSIANG, Solomon M.; BURKE, Marshall; MIGUEL, Edward. Quantifying the influence of climate on human conflict. Science, v. 341, n. 6151, 2013. https://doi. org/10.1126/science. 1235367

IM, Eun-Soon; PAL, Jeremy S.; ELTAHIR, Elfatih A. B. Deadly heat waves projected in the densely populated agricultural regions of South Asia. Science Advances, v. 3, n. 8, 2017. https://doi.org/10.1126/sciadv.1603322

JAMESON, Fredric. An American utopia: dual power and the universal army. Slavoj Žižek (ed.). London: Verso, 2016.

KELLEY, Colin P.; MOHTADI, Shahrzad; CANE, Mark A.; SEAGER, Richard; KUSHNIR, Yochanan. Climate change in the Fertile Crescent and implications of the recent Syrian drought. PNAS, v. 112, n. 11, p.3241-3246, 2015. https://doi. org/10.1073/pnas.1421533112

KOCINA, Petr. Should international law continue to start from a presumption of the sovereignty of states in relation to immigration policy? Philosophica Critica, [S. l.], v. 3, n. 1, p. 59-66, 2017.

LOVELOCK, James. The revenge of Gaia: why the earth is fighting back - and how we can still save humanity. Santa Barbara: Allen Lane, 2006. https://doi.org/10.1558/ ecot.v11i4.523

LOVELOCK, James. A rough ride to the future. New York: The Overlook Press, 2014.

MISSIRIAN, Anouch; SCHLENKER, Wolfram. Asylum applications respond to temperature fluctuations. Science, v. 358, n. 6370, p. 1610-1614, 2017. https://doi. org/10.1126/science.aao0432

MRAVCOVA, Anna. Education for sustainable development and global citizenship in the current globalized world. In: Managerial trends in the development of enterprises 
in globalization era. Ingrida Košičiarová; Zdenka Kádeková (eds.). Nitra: Slovak University of Agriculture in Nitra, 2017. p.630-641. https://doi.org/10.21272/mmi. 2017.3-16

PARK, Chang-Eui; JEONG, Su-Jong; JOSHI, Manoj; OSBORN, Timothy J.; $\mathrm{HO}$, Chang-Hoi; PIAO, Shilong et al. Keeping global warming within $1.5^{\circ} \mathrm{C}$ constrains emergence of aridification. Nature Climate Change, v. 8, p. 70-74, 2018. https://doi. org/10.1038/s41558-017-0034-4

RASMUSSEN, Sune Engel. How climate change is a 'death sentence' in Afghanistan's highlands. The Guardian, 28 Aug 2017. Available at: www.theguardian.com/ world/2017/aug/28/how-climate-change-is-death-sentence-afghanistan-highlandsglobal-warming.

SCHLEUSSNER, Carl-Friedrich; DONGES, Jonathan F.; DONNER, Reik V.; SCHELLNHUBER, Hans Joachim. Armed-conflict risks enhanced by climate-related disasters in ethnically fractionalized countries. PNAS, v. 113, n. 33, p.9216-9221, 2016. https://doi.org/10.1073/pnas.1601611113

SKLAIR, Leslie. Half-Baked. Philosophica Critica, [S.l.], v. 2, n. 1, p. 103-116, 2016.

STEFFEN, Will; PERSON, Åsa; DEUTSCH, Lisa; ZALASIEWICZ, Jan; WILLIAMS, Mark; RICHARDSON, Katherine et al. The anthropocene: from global change to planetary stewardship. Ambio: A Journal of the Human Environment, v. 40, n. 7, p. 739-761, 2011. https://doi.org/10.1007/s13280-011-0185-x

STEFFEN, Will; BROADGATE, Wendy; DEUTSCH, Lisa; GAFFNEY, Owen; LUDWIG, Cornelia. The trajectory of the Anthropocene: the great acceleration. The Anthropocene Review, [S.l.], v. 2, n. 1, p.81-98, 2015. https://doi.org/ $10.1177 / 2053019614564785$

SŤAHEL, Richard. Environmental limits of personal freedom. Philosophica Critica, v. 2, n. 1, p. 3-21, 2016 a.

SŤAHEL, Richard. Environmental crisis and political revolutions. In: Johann P. Arnasson; Marek Hrubec (eds.). Social transformations and revolutions: reflections and analyses. Edinburgh: Edinburgh University Press, 2016b, p.99-120. https://doi. org/10.3366/edinburgh/9781474415347.003.0006

SŤAHEL, Richard. Climate change and social conflicts. Perspectives on Global Development and Technology, [S.l.], v. 15, n. 5, p.480-496, 2016c. https://doi. org/10.1163/15691497-12341403

SŤAHEL, Richard. Self-limitation as the basis of environmentally sustainable care of the self. Human Affairs, v. 27, n. 4, p.444-454, 2017. https://doi.org/10.1515/ humaff-2017-0036

THE ENVIRONMENTAL Justice Foundation. Beyond borders: our changing climate - its role in conflict and displacement, 2017. Available: https://ejfoundation.org// resources/downloads/BeyondBorders-2.pdf. 
TOKAR, Brian. Toward climate justice: perspectives on the climate crisis and social change. Porsgrunn: New Compass Press, 2014.

UN. Transforming our world: the 2030 agenda or sustainable development, 2015a. Available: https://sustainabledevelopment.un.org/content/documents/21252030\%20 agenda $\% 20$ for $\% 20$ sustainable $\% 20$ development $\% 20$ web.pdf.

UN. Framework Convention on Climate Change (adoption of the Paris Agreement), 2015b. https://unfecc.int/resource/docs/2015/cop21/eng/109r01.pdf.

UNHCR. Figures at a glance, 2017. Available: www.unher.org/figures-at-a-glance. html.

WFP, UNEP and NEPA. Climate change in afganistan - what does it mean for rural livelihoods and food security? 2016. Available: www.wfp.org/sites/default/files/ WFP UNEP NEPA Afghanistan_Impacts climate \%20change.pdf. https://doi. org/10.2458/azu_acküserial_hv696_f6_u65_3rd_quarter_2002.

WHO and UNICEF. Progress on drinking water, sanitation and hygiene: 2017 update and SDG baselines. Geneva: World Health Organization (WHO) and the United Nations Children's Fund (Unicef), 2017. Available: www.unicef.org/publications/ index_96611.html. https://doi.org/10.1163/1570-6664_iyb_sim_org_2298.

WMO. The state of greenhouse gases in the atmosphere based on global observations through 2016. WMO Greenhouse Gas Bulletin, n. 13, 30 Oct. 2017. Available: https:// ane4bf-datap1.s3-eu-west-1.amazonaws.com/wmocms/s3fs-public/ckeditor/files/ GHG_Bulletin_13_EN_final_1_1.pdf?LGJNmHpwKkEG2Qw4mEQjdm6bWxgWA JHa.

Received at: 29 Sept. 2018

Aproved at: 15 Jan. 2019

Published at: 30 July 2019

Corresponding author:

Richard St'ahel

Klemensova 19

81108 Bratislava, Slovakia

RICHARD SŤAHEL <richard.stahel@savba.sk>

Institute of Philosophy, Slovak Academy of Sciences (Bratislava, Slovakia)

Orcid: https://orcid.org/0000-0002-1665-5795 